\title{
Research of Financial Support for Agricultural Development
}

\author{
Sun Yan \\ School of Economics and Management, Heilongjiang Bayi Agricultural University, Daqing, China \\ Email address: \\ byndsy@126.com \\ To cite this article: \\ Sun Yan. Research of Financial Support for Agricultural Development. Journal of Business and Economic Development. \\ Vol. 5, No. 1, 2020, pp. 21-25. doi: 10.11648/j.jbed.20200501.13
}

Received: January 15, 2020; Accepted: January 27, 2020; Published: February 12, 2020

\begin{abstract}
Agriculture is an important industry that affects the national economy and people's livelihood. It is also an important guarantee for supporting the development of industry and service industry, and plays a fundamental role in the entire national economy. With the development of science and technology since the new century, the various policies issued by the state to benefit farmers and strong farmers have played a role in promoting agricultural development and increasing farmers' income. However, with the development of the economy, the improvement of people's living standards and the improvement of environmental awareness, the focus of agricultural development has begun to change, focusing on the adjustment of agricultural structure, ecological recycling agriculture and agricultural tourism. The development of agriculture is inseparable from the strong support of finance. In particular, rural financial institutions should make serving agriculture their starting point and foothold, and allocate more resources to the key areas and weak areas of agriculture in order to offer good service to agricultural development and make sustainable development for themselves. Therefore, this paper starts from the current key areas of agricultural development, explores the path of agricultural financial service, and provides financial support for key areas of agricultural development, with a view to assisting agricultural development.
\end{abstract}

Keywords: Financial Institutions, Financial Innovation, Agricultural Development, Government

\section{Introduction}

Agriculture is a country's basic industry and the material basis for human existence. In recent years, the state has promulgated a series of policy documents, which has largely promoted the development of high-quality agriculture and increased farmers' income. But as China's social-economic development enters a new stage, people's living standards continue to increase, environmental protection awareness is constantly increasing, and agricultural economic development is also facing many difficulties. There is a disconnect between the agricultural supply structure and the market demand structure, the resource utilization rate is not high, and the ecological environment is deteriorating. The integration of agriculture and other industries is not high. These issues impede the quality and sustainable development of agriculture. Therefore, adjustments are needed to promote the development of the agricultural industry. Financial support is considered to be an effective driving force for the development of modern agriculture [1]. Regardless of the high-risk, low-return and long-cycle characteristics, agricultural industry as a "short board" has been producing in recent years with the structural reform of the agricultural supply side and the implementation of rural strategies. However, the pressure of rising costs is increasing, and the financial needs for agricultural development have not been effectively met. Therefore, financial institutions should provide financial services, carry out financial innovation, and provide financial support in accordance with the current key areas of agricultural development. Financial support is an important force in the process of agricultural development. Financial support helps to solve the problem of insufficient funds for "agriculture, rural areas, and farmers", and provides necessary financial guarantees for risks in agricultural development; it is conducive to the effective use of financial leverage, complementing rural agricultural shortcomings, and promoting high-quality agricultural development [2]. At the same time, it also provides space for the transformation and upgrading of financial institutions, especially agricultural-related financial institutions, and lays 
the foundation for the sustainable development of rural financial institutions. Starting from the key areas of agricultural development, this paper makes a continuous exploration of financial support for agricultural development, and proposes specific paths for financial support for agricultural development, with a view to providing the necessary financial guarantee for China's agricultural development.

\section{Key Areas of Agricultural Development in China}

\subsection{Agricultural Industry Structure Adjustment}

For a long time, the traditional concept of grain as the standard and production as the scale has led to structural overproduction, and the agricultural industrial structure has also shown an uneven state. Among the agriculture, forestry, animal husbandry and fishery, the proportion of agriculture dominated by rice, corn and soybean is large, and the proportion of forestry and fishery accounts for a small proportion [3]. Many traditional agricultural products cannot meet the growing needs of enterprises and residents. In particular, large-scale leading enterprises need high-quality agricultural products as basic production materials. Common agricultural products have no market or low market share, and are not conducive to production efficiency and the increase of farmers' income. Agriculture faces a disconnect between the supply structure and the market demand structure. Therefore, agricultural production is no longer focused on the development of total volume, but should focus on the quality of agricultural supply. All regions should adjust and optimize the agricultural industrial structure by combining their own natural conditions and using domestic and foreign markets, information conditions, and consumer demand. Promote the development of other industries through the extension of the industrial chain, such as the development of the crop industry through the development of animal husbandry. It can be seen that in the process of agricultural development, we should pay attention to the adjustment of the agricultural industrial structure, consider the market demand, and produce green, high-quality products that meet the needs of residents and enterprises [4].

\subsection{Ecological Cycle Agriculture}

Traditional agricultural development and economic growth are at the expense of resource consumption. Despite the large amount of resources in China, due to the inefficient use of resources and weakened ecological awareness, problems such as low resource allocation efficiency and serious environmental pollution have emerged in the process of agricultural development. The resources are becoming increasingly tense and the ecological environment is deteriorating. In order to solve this problem fundamentally, we should pay attention to the development of ecological recycling agriculture [5]. In the development of agricultural industrialization, we will take advantage of the scale effect and regard industrialization development as the direction of circular agriculture development. In the use of agricultural resources, we pay attention to cost savings, reduce resources input from water saving, energy saving, land saving and savings, and improve the efficiency of resource use. For example, based on enzyme engineering and cell engineering, the development of "white agriculture" through the comprehensive utilization of genetic engineering, the development of microbial engineering science, and the realization of water-saving, soil-saving and resource recycling. In the aspect of agricultural waste treatment, the comprehensive utilization of resources is carried out, and the biological resources accumulated in the production of crops are comprehensively utilized. For example, through the mode of rice raising ducks, using livestock and poultry excrement fertilizer fields, or performing anaerobic fermentation, producing biogas to provide energy for production and life. At the same time, biogas residue and biogas slurry are good organic feeds and fertilizers. The livestock and poultry excrement will be resourced through certain technical treatments, and recycled between planting and breeding industries [6]. Ecological recycling agriculture is an important guarantee for the sustainable development of agriculture. It is a long-term project that requires a large amount of capital investment. The funding problem is a key issue that restricts the development of agricultural circular economy [7].

\subsection{Agricultural Tourism}

In recent years, with the development of the economy, people's consumption capacity has been continuously improved, creating opportunities for the development of rural tourism. Agricultural tourism has become a new growth point for rural economic development, which is of positive significance for farmers to continue to increase income and promote rural economic development [8]. Agricultural tourism is not only the integration of agriculture and tourism, but also covers a wide range of industries such as agriculture, forestry, animal husbandry and fishery. On the basis of making full use of agricultural production and agricultural resources, it integrates tourism, leisure and experience. A new type of industry. Focusing on the fruit and vegetable gardens, we will carry out tourism activities such as self-picking, self-control, and self-driving, which are closely related to the tourism and urban areas, and establish tourism tourism development projects through policy means. For example, the fishing village experience activities focusing on the villages along the rivers, the rural experience activities with the theme of pure natural fruit and vegetable picking and self-made, and the forestry experience activities focusing on the original forest. To develop agricultural tourism, we must combine the characteristics of the environment, create our own service characteristics, and shape the brand image. Enrich the connotation of the tourism industry by building green eco-type, cultural economy, high-tech and other eco-tourism products. 


\section{Analysis of the Path of Financial Support for Agriculture}

\subsection{Optimize the Allocation of Financial Resources to Promote the Adjustment of Agricultural Industry Structure}

Financial support for agriculture should be better suited to agricultural development. Governments and financial institutions should guide excess credit resources into agricultural development, increase support and development of high-quality agricultural products industry, and promote the adjustment of agricultural industrial structure. First, in the process of agricultural development, the government should increase investment in new agricultural products and new processes, improve the efficiency of capital investment, and promote the innovative development of the agricultural industry. At the same time, different evaluation systems and supervision mechanisms should be provided for different financial institutions, and certain tax incentives and policy subsidies should be given to agricultural financial institutions that actively carry out rural financial services, and the supply of agricultural funds should be guided through policies to promote structural adjustment [9]. Second, financial institutions promote the adjustment of China's agricultural industry structure through loans, quotas, deadlines, and financial innovations [10]. Financial institutions, especially agriculture-related financial institutions, should consider the current focus of China's agricultural development, implement a credit policy with a guaranteed pressure, improve the credit line of green and high-quality agricultural products, guide the transfer of credit funds to industries supported by the state, and guide agriculture. Branding and ecological development. On the contrary, high-inventory agricultural and livestock products with low consumer demand for residents and enterprises should reduce the credit line and guide their transformation. In addition, rural financial institutions expand the scope of effective collateral and explore various mortgage guarantee models such as chattel mortgage, forest tenure mortgage, and warehouse receipt pledge [11].

\subsection{Development of Green Finance to Help Ecological Recycling Agriculture}

Eco-circulating agriculture has high requirements for technology and capital. The externality and long-term characteristics of science and technology determine that agricultural science and technology investment is an investment method that is dominated by government investment and supplemented by various investment methods of society. On the one hand, the government must implement agricultural budget expenditures, increase investment in scientific research infrastructure, experimental bases, instruments and equipment, and provide good scientific research conditions for ecological recycling agricultural innovation [12]. At the same time, through the policy adjustment of environmental protection subsidies, tax reductions and other aspects of production, management, transportation and other aspects to guide farmers to green production, reduce the use of chemical fertilizers and pesticides, and guide the transformation of agriculture to green sustainable development and high quality development.

On the other hand, financial institutions should pay more attention to the development of green agricultural industry, and should strengthen financial innovation [13]. Promoting the development of eco-circulating agriculture through the development of green finance requires financial institutions to implement differentiated credit policies, and to provide funds for the agro-ecological cycle, resource reuse, green products, and production of organic agricultural products, and to guide credit funds transfer such as rural ecological economic construction and ecological farming demonstration projects. At the same time, we will innovate the financial service model, establish a product system including green credit, green leasing, green investment and underwriting of green debt financing instruments, accelerate the innovation of green credit collateral, and help the traditional agricultural industry develop towards green, environmental protection and sustainable development.

\subsection{Broaden Financing Channels and Promote the Integration of Agriculture and Tourism}

Agricultural tourism is a fusion of tourism and agriculture. It is a new type of industry and should enjoy the preferential policies of the state. The government should set up special development funds for different regions and different projects for rural road construction, communication facilities construction and environmental transformation, and provide preferential measures such as subsidies, subsidies, tax reductions and exemptions for the development of agricultural tourism-related industries. Financial institutions should vigorously support the development of agricultural tourism. The agriculture-related financial institutions should analyze the financial needs of the region and provide effective financial supply based on the development of agricultural industry in the region, from the perspective of financing willingness, interest rate sensitivity, and use of financial products. Develop a variety of loans suitable for agricultural tourism. [14]. For projects that are focused on development and effective, financial funding is tilted. In addition to government and financial institutions, the development of agricultural tourism requires the extensive participation of all parties in the society. Product innovation, platform innovation, and ppp mode should be used to guide private capital to provide financial support for rural tourism and promote the integration of agriculture and tourism [15].

\section{Conclusion}

Agriculture is a country's basic industry, which is characterized by high risks, low returns, and long cycles. In recent years, economic growth, the improvement of consumption capacity, and changes in the structure of people's demand have brought some new problems to agricultural development and created certain opportunities. For example, 
the traditional concept of grain production as the scale has led to structural overproduction, and agriculture has faced a disconnect between the supply structure and the market demand structure; traditional agricultural development resources have low utilization efficiency, weakened ecological consciousness, and agricultural development processes. Problems such as inefficient allocation of resources and serious environmental pollution have occurred in China; but at the same time, the improvement of people's social consumption capacity has created opportunities for the development of rural tourism and a new growth point for rural economic development. Therefore, the key areas of China's agricultural development should be in adjusting agricultural industrial structure, attaching importance to ecological circular agriculture, and developing agricultural tourism.

The high-quality and sustainable development of agriculture is inseparable from the support of finance, which can promote the rational and efficient allocation of resources. Financial capital is an important factor affecting agricultural development. Rural areas have less capital accumulation and greater risks. Therefore, the rational introduction of financial support to agriculture is the key to solving the problems of agriculture, rural areas, and farmers. The development of the rural economy and the improvement of farmers' income are inseparable from financial support. Financial institutions should define the key areas of financial support for agriculture, and provide financial services, carry out financial innovation, and provide financial support in combination with the current key areas of agricultural development to ensure that financial support for agriculture achieves targeted assistance and improves the effectiveness of financial resources. This article starts with the key areas of agricultural development, such as agricultural structure adjustment, ecological recycling agriculture, and agricultural tourism, and proposes financial support for agriculture.

The first is to optimize the allocation of financial resources and promote structural adjustment of the agricultural industry. In the process of agricultural development, the government should increase investment in new agricultural products and processes, improve the efficiency of capital investment, and promote the innovation and development of the agricultural industry; promote the development of China's agriculture through the adjustment of loan scope, quota, term, and financial innovation. Adjustment of industrial structure. The second is the development of green finance to promote ecological recycling agriculture. Government departments should increase investment in scientific research infrastructure, experimental bases, equipment, and other resources to provide good scientific research conditions for ecological circular agricultural innovation. Government departments can also guide agriculture to green sustainable development and high-quality development through policy adjustments such as environmental subsidies and tax reductions. Financial institutions should implement differentiated credit policies and establish green credit, green leases, green investments, and green debt financing instruments. And other product systems, innovate financial service models, and promote the development of ecological circular agriculture. The third is to expand financing channels and promote the integration of agriculture and tourism. Agricultural-related financial institutions should develop a variety of loan types suitable for agricultural tourism based on the development of the agricultural industry in their region. With the help of product innovation, platform innovation, and ppp mode, private capital is guided to provide financial support for rural tourism and promote the integration of agriculture and tourism. Financial support for agriculture provides strong economic support for the development of agriculture. Financial support for agriculture is an important foundation for promoting agricultural development and achieving farmers' income.

\section{Acknowledgements}

This article is the phased research result of a project from "Campus Cultivating Projects Funding Plan" of Heilongjiang Bayi Agricultural University (Project Title: Influencing Factors and Countermeasures of Farmers' Income in Heilongjiang Reclamation Area under the Background of Agricultural Supply Side Structural Reform, Project Number: XRW2017-04). The formation of the results is inseparable from the help of all parties. Thanks to Heilongjiang Bayi Agricultural University for its support in funding and resources, and thanks to my colleagues and friends for their help in gathering information and translating.

\section{References}

[1] Cheng, X. J. "Research on financial support issues in Henan agricultural modernization development", Rural Economy and Technology, vol. 6. 2019, pp. 97-99.

[2] Guo, J. L. "The path choice of rural finance supporting rural revitalization strategy: based on the cases of 11 provincial agricultural credits in China", Southwest Finance, vol. 8. 2019, pp. 54-62.

[3] Sun, Y. and Hou H. C. "Research on the problem of increasing farmers' income in Heilongiiang reclamation area under the background of structural reform of agricultural supply side", Journal of Heilongjiang Bayi Agricultural University, vol. 1. 2018, pp. 96-99.

[4] Liu N. A., Guo, Q. H. and Han, Y. H. "Analysis of the path of increasing farmers' income in China under the reform of agricultural supply side structure", Taxation \& Economy, vol. 2 . 2017, pp. 35-40.

[5] Hong R., Kang N. and Song, Z. "Discussion on the legal issues in financial support for regional recycling agriculture", Agricultural Economy, vol. 8. 2018, pp. 98-100.

[6] Yang, Q. Y. "Developing ecological cycle agriculture to lead green transformation in agriculture", Farm Economic Management, vol. 5. 2018, pp. 27-30.

[7] Zhao, J. Y. "Research on the sustainable development of agricultural Eco-economy under the new circumstances", Agriculture and Economy, vol. 3. 2017, pp. 25-26.

[8] Yu, F. W. "Rethinking the development of rural tourism in the new era", Environmental Protection, vol. 2. 2019, pp. 14-18. 
[9] Liang X. Z. "Reflections on deepening the structural reform of rural financial supply side_- taking Henan as an example", Rural Economy, vol. 5. 2018, pp. 57-62.

[10] Ji, X. C. and Ding, H. X. "The impact of finance on agricultural structural reform-taking Weifang City of Shandong Province as an example", Shanxi Agricultural Economics, vol. 17. 2018, pp. 43.

[11] He, B. B. "Research on the contradiction between supply and demand of rural urbanization financial services in Zhongyuan Economic Zone", Economic and Trade Practice, vol. 8. 2017, pp. 36-37.

[12] Yang, Q. and Liu, Z. "Research on financial support for agricultural circular economy development—-based on analysis of farmers' willingness to behave", Rural Economy, vol. 9. 2017, pp. 88-93.

[13] Kou, S. Y. "The development of green finance and the challenges faced by rural commercial banks", Economic and Trade Practice, vol. 11. 2018, pp. 131.

[14] Gao, Y. and Li, C. "Practice and reflection on the structural reform of agriculture supply side in financial services", Rural Economy, vol. 7. 2019, pp. 94-95.

[15] Li, X. Y. and Shi, A. L. "Structured finance promotes the coordinated development of circular agriculture and agricultural insurance", vol. 4. 2019, pp. 34-38. 